\title{
In Utero Exposure to Organic Pollutants and Lung Function in the Offspring
}

\author{
Alicia Abellan, $\mathrm{MSc}^{1,2,3,4}$ and Maribel Casas, $\mathrm{PhD}^{1,2,3}$
}

${ }^{1}$ ISGlobal, Barcelona; ${ }^{2}$ Pompeu Fabra University, Barcelona; ${ }^{3}$ Spanish Consortium for Research on Epidemiology and Public Health (CIBERESP), Madrid;

${ }^{4}$ Fundació Institut Universitari per a la recerca a l'Atenció Primària de Salut Jordi Gol i Gurina (IDIAPJGol), Barcelona. Spain

\section{ABSTRACT}

Humans are exposed daily to thousands of chemicals present in many consumer products that can interfere with hormonal signalling systems. The prenatal period is critical because the developing lung is intrinsically subject to hormonal regulation. Alterations at this time may predispose to reduced lung function in later life. In this review, we summarise current knowledge about the role of prenatal exposure to organic pollutants on lung function in the offspring. We divide pollutants into persistent: organochlorine and perfluoroalkyl compounds, and non-persistent: bisphenols, parabens, triclosan, benzophenones, phthalates, and currently used pesticides. Eleven prospective cohort studies, mainly from Europe and the US, have been identified. Overall, the literature is scarce and inconsistent. The observed associations have identified small changes in lung function parameters. Main challenges for future studies include assessment of exposure to non-persistent pollutants and the study of multipollutant effects. In parallel, public health strategies should be implemented to reduce exposure to organic pollutants, particularly in pregnant women. (BRN Rev. 2021;7(1):62-79)

Corresponding author: Maribel Casas, maribel.casas@isglobal.org

Keywords: Childhood. Endocrine disrupting chemicals. Lung function. Pregnancy. 


\section{INTRODUCTION}

Impaired lung development in early life may predispose individuals to reduced lung function in adulthood ${ }^{1,2}$. This can lead to persistent respiratory morbidity and chronic respiratory diseases later in life ${ }^{3,4}$. Chronic respiratory diseases are among the leading causes of mortality and morbidity worldwide and asthma and chronic obstructive pulmonary disease (COPD) are the most common - 358 million people are affected by asthma and 175 million by $\mathrm{COPD}^{5}$. There is no curative therapy for either of them. The natural history of both diseases is extensive yet incomplete. It is postulated that they have at least part of their origins in early life when the lung is still undergoing rapid development ${ }^{6,7}$. This fits well with the concept of the Developmental Origins of Health and Disease, which describes how early-life exposures may have a long-term impact on disease in adulthood $^{8}$. Identification of early determinants of lung development is of utmost importance, given their long-term effect on disease throughout life.

The developing lung is extremely susceptible to the effects of environmental exposures 9 . Exposure to an adverse environment during critical periods of pre- and early postnatal life might lead to developmental adaptations resulting in impaired lung growth with smaller airways and lower lung volume, altered immunological responses, and related inflammation. The dramatic increase in childhood asthma prevalence over the last decades ${ }^{5}$ has raised concerns about the potential role of environmental pollutants. Exposure to a number of common environmental pollutants, including environmental tobacco smoke ${ }^{10}$ and air pollution ${ }^{11,12}$ has been associated with childhood respiratory tract illnesses. More recent$1 y$, concern is growing over the impact of environmental chemicals on childhood lung function.

Environmental chemicals can be classified within organic and inorganic pollutants. Organic pollutants include polychlorinated biphenyls (PCBs), pesticides, perfluoroalkyl substances (PFASs), phenols, and polyaromatic hydrocarbons (PAHs), among others; inorganic pollutants include a variety of heavy metals such as mercury, lead, arsenic, or cadmium. Both organic and inorganic pollutants present in the environment may have the capacity to interfere with the endocrine system and consequently alter many essential body functions such as growth, behaviour, and reproduction ${ }^{13}$. The term "endocrine disrupting chemical" includes a large number of substances (in some lists more than $1,500^{14}$ ) whose primary effect is on the endocrine system through interaction with cellular hormone receptors, hormone synthesis or clearance ${ }^{13}$. Endocrine disrupting chemicals can have effects at very low exposure levels, as endogenous hormones do; low doses can have more potent effects than higher doses; and exposure to multiple chemicals can result in synergistic, antagonistic, or cumulative effects ${ }^{15}$.

Endocrine disrupting chemicals are produced in large quantities worldwide (millions of tons annually) and consequently, human populations are continuously exposed to them through food, food packaging, cosmetics, dust inhalation, and consumer products. Human biomonitoring studies have shown low but very widespread human exposure ${ }^{16-18}$. Exposure to these chemicals is of special concern 
TABLE 1. Concentrations of organic pollutants in 1,301 pregnant women and children in 6 European population-based cohort studies participating in the HELIX project (extracted from Haug et al. ${ }^{18}$ with permission from the author)

\begin{tabular}{|c|c|c|c|c|c|c|}
\hline \multirow[t]{2}{*}{ Pollutant } & \multicolumn{3}{|c|}{ Maternal samples } & \multicolumn{3}{|c|}{ Child samples } \\
\hline & $\begin{array}{c}\% \text { quantifiable } \\
\text { samples }\end{array}$ & $\begin{array}{l}\text { Median } \\
\text { (P25-P75) }\end{array}$ & Max & $\begin{array}{l}\% \text { quantifiable } \\
\text { samples }\end{array}$ & $\begin{array}{l}\text { Median } \\
\text { (P25-P75) }\end{array}$ & Max \\
\hline \multicolumn{7}{|c|}{ Organochlorine compounds - blood (ng/g lipid) } \\
\hline DDE & 99.9 & $52.3(25.9,111)$ & 1903 & 100 & $21.8(11.6,45.6)$ & 2158 \\
\hline PCB-153 & 99.6 & $17.6(10.4,30.5)$ & 214 & 100 & $11.6(7.28,18.6)$ & 217 \\
\hline HCB & 99.1 & $8.16(5.59,13.0)$ & 164 & 99.9 & $8.19(6.27,11.4)$ & 88.1 \\
\hline \multicolumn{7}{|c|}{ Perfluoroalkyl substances - blood ( $\mu \mathrm{g} / \mathrm{L})$} \\
\hline PFOS & 100 & $6.41(4.12,9.63)$ & 48.0 & 99.8 & $2.03(1.26,3.22)$ & 33.8 \\
\hline PFOA & 99.7 & $2.30(1.38,3.34)$ & 31.6 & 100 & $1.55(1.19,1.97)$ & 6.66 \\
\hline \multicolumn{7}{|c|}{ Bisphenols - urine ( $\mu \mathrm{g} / \mathrm{g}$ creatinine) } \\
\hline Bisphenol A & 99.4 & $2.82(1.55,6.60)$ & 107 & 98.3 & $4.06(2.42,7.17)$ & 362 \\
\hline \multicolumn{7}{|c|}{ Parabens, Triclosan, and Benzophenones - urine ( $\mu \mathrm{g} / \mathrm{g}$ creatinine) } \\
\hline Methyl-paraben & 99.8 & $167(39.5,389)$ & 39,241 & 99.7 & $6.50(3.28,26.4)$ & 23,963 \\
\hline Ethyl-paraben & 97.4 & $6.26(1.14,26.72)$ & 817 & 99.3 & $0.67(0.43,1.22)$ & 2033 \\
\hline Triclosan & 98.5 & $6.28(1.50,79.9)$ & 1653 & 100 & $0.61(0.32,1.5)$ & 702 \\
\hline Benzophenone-3 & 99.3 & $4.90(1.46,27.5)$ & 12,837 & 99.9 & $2.16(0.86,6.96)$ & 7985 \\
\hline \multicolumn{7}{|c|}{ Phthalates - urine ( $\mu \mathrm{g} / \mathrm{g}$ creatinine) } \\
\hline DEHP metabolite MEHP & 99.5 & $8.73(4.42,15.3)$ & 417 & 96.8 & $2.88(1.70,5.10)$ & 282 \\
\hline MiBP & 99.9 & $38.7(23.3,60.7)$ & 705 & 100 & $41.8(25.9,73.3)$ & 861 \\
\hline \multicolumn{7}{|c|}{ Currently used pesticides - urine ( $\mu \mathrm{g} / \mathrm{g}$ creatinine) } \\
\hline DAP metabolite DMP & 90.8 & $8.37(4.13,16.4)$ & 321 & 49.3 & $0.78(0.29,4.70)$ & 83.3 \\
\hline DAP metabolite DEP & 97.8 & $3.33(1.86,6.44)$ & 198 & 80.9 & $1.83(0.47,4.52)$ & 665 \\
\hline
\end{tabular}

$\%$ quantifiable samples: $\%$ of the biomarker measurements with concentrations reported.

DAP: dialkyl phosphate; DDE: dichlorodiphenyldichloroethylene; DEHP: di-(2-ethylhexyl) phthalate; DEP: diethyl phosphate

DMP: dimethyl phosphate; HCB: hexachlorobenzene; MEHP: mono-2-ethylhexyl phthalate; MiBP: mono-isobutyl phthalate; P25: 25th percentile; P75: 75th percentile;

PCB-153: polychlorinated biphenyl-153; PFOA: perfluorooctanoate; PFOS: perfluorooctane sulfonate.

in pregnant women and children, with many compounds being detected in more than $90 \%$ of samples (Table 1). Foetus and infants are especially sensitive to chemicals that mimic hormones because the protective mechanisms (i.e., detoxification) existing in adulthood are not completely functional in early life. In the $\mathrm{EU}$, the medical cost associated with exposure to endocrine disrupting chemicals has been estimated at $€ 163$ billion a year ${ }^{19}$. Nowadays, the reduction of exposure to endocrine disrupting chemicals, and particularly the organic ones, represent a priority for action in the European Commission owing to their high annual production and potential toxicity ${ }^{20}$.

In this narrative review, we summarize current knowledge about the role of exposure 
to organic pollutants during pregnancy on lung function in the offspring. We have focused the review on the prenatal exposure because is when the lung is more susceptible to the effects of harmful environmental exposures ${ }^{9}$. This summary is mainly based on epidemiological literature published between 2014 and 2020. We have primarily identified relevant literature using the PubMed search engine (National Library of Medicine). Search strategies include keywords for the various combinations of organic pollutants (organochlorine compounds (OCs), PCBs, dichlorodiphenyldichloroethylene (DDE), hexachlorobenzene (HCB), PFASs, bisphenols, parabens, triclosan, benzophenone-3, phthalates, and organophosphate pesticides) and respiratory function (lung function, spirometry, forced expiratory volume in one second $\left[\mathrm{FEV}_{1}\right]$, forced vital capacity [FVC], $\mathrm{FEV}_{1} / \mathrm{FVC}$ ratio, and forced expiratory flow at $25-75 \%$ ). We have divided organic pollutants into persistent, characterized as having long biological half-lives in the body (e.g., from months to years), and non-persistent, with short biological half-lives (e.g., from hours to days).

\section{OVERVIEW OF LUNG DEVELOPMENT}

The development of the lung starts at the foetal stage and continues after birth until 20 years of age. It consists of five consecutive stages: embryonic, pseudoglandular, canalicular, saccular, and alveolar (Fig. 1). Primary lung buds start to develop at the 4th week of gestation to form the trachea, bronchi, and pulmonary vein and artery. During the second trimester of pregnancy, during the pseudoglandular and canalicular stages, the bronchi continue their segmentation, primitive alveoli are formed, and the synthesis of surfactant starts. This is considered to be the most critical stage for the respiratory system since it is when all conducting airways are formed. The saccular and alveolar are the last prenatal stages. They develop from the third trimester of gestation until the second year after birth. During these stages, the gas exchange region expands. The expansion triggers the production of extracellular matrix, collagen, and elastin. During these phases, there is further growth of the vascular system associated with the respiratory system. After birth and until the second year of age, alveoli continue developing. The gas exchange regions keep expanding through a branching process in concordance to its associated vascular and nervous systems. From two years until adulthood, the process of lung growth and expansion continues by a sustained cellular proliferation ${ }^{9,21}$. Across the lifespan, lung function grows from birth to late adolescence, reaching its maximal levels in early adulthood. This is followed by a plateau period when lung function remains stable for several years before it starts to gradually decline ${ }^{22}$.

The developing lung is intrinsically subject to endogenous hormonal regulation ${ }^{9,23,24}$ : glucocorticoids, oestrogens, and thyroid hormones promote the structural development of the lung and the production of pulmonary surfactant, while androgens retard surfactant production. Other receptors also play a prominent role on lung development: aryl hydrocarbon receptor (AhR) activation decrease thyroid hormone levels and peroxisome proliferator-activated receptor (PPAR) alter airway cell differentiation and surfactant 


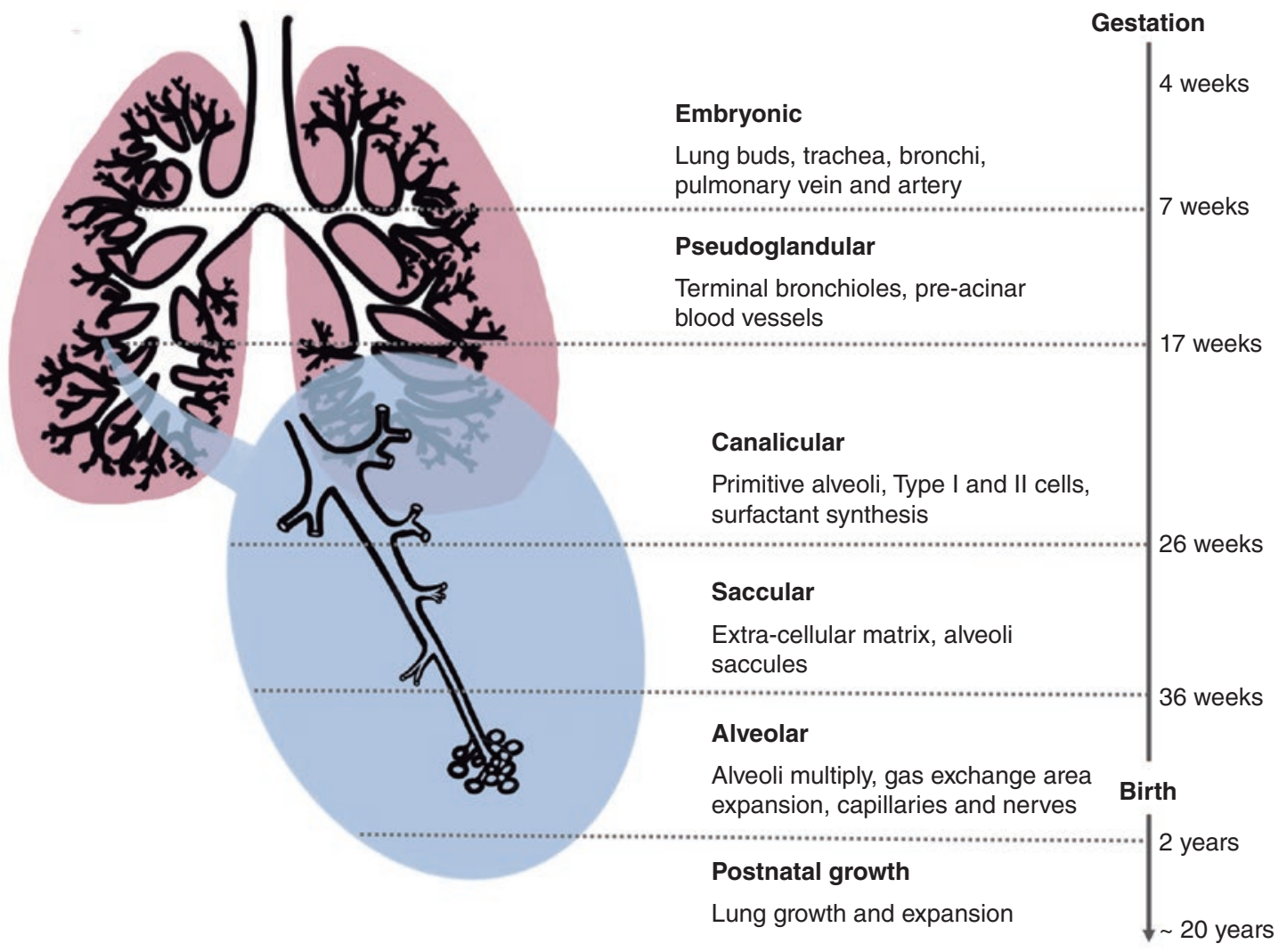

Figure 1. Developmental stages of the lung.

production, among other mechanisms. All these receptors are expressed in the human lung'. Of concern, endocrine disrupting chemicals have affinity with glucocorticoids (e.g. pesticides), oestrogens (e.g. bisphenols, pesticides), androgens (e.g. phthalates), and/or thyroid hormones receptors (e.g. bisphenols, metals), to AhR (e.g. pesticides), and/or PPAR (e.g. perfluoroalkyl compounds) ${ }^{25-28}$. Hence, disruption of fundamental biologic processes and associated signalling events due to exposure to endocrine disrupting chemicals may result in significant alterations in lung development.

\section{PERSISTENT ORGANIC POLLUTANTS AND LUNG FUNCTION}

\section{Organochlorine compounds}

OCs are synthetic persistent organic pollutants mainly used as pesticides or in industrial products such as electrical insulators and flame retardants (Table 2). Their use and production of some of these compounds has been banned for decades ${ }^{29,30}$. For example, the former widely used pesticide dichlorodiphenyl-trichloroethane (DDT) was banned 
TABLE 2. Main sources of exposure to organic pollutants

\begin{tabular}{|c|c|c|}
\hline & Pollutants & Main sources of exposure \\
\hline \multirow[t]{2}{*}{$\begin{array}{l}\text { Persistent organic } \\
\text { pollutants }\end{array}$} & Organochlorine compounds & $\begin{array}{l}\text { Pesticides } \\
\text { Electrical insulators } \\
\text { Industrial products }\end{array}$ \\
\hline & Perfluoroalkyl substances & $\begin{array}{l}\text { Surfactants for industrial products coating (i.e., paper packaging, textile, leather) } \\
\text { Fire-fighting foams } \\
\text { Lubricants } \\
\text { Photography industry } \\
\text { Non-stick cookware }\end{array}$ \\
\hline \multirow[t]{4}{*}{$\begin{array}{l}\text { Non-persistent organic } \\
\text { pollutants }\end{array}$} & Bisphenols & $\begin{array}{l}\text { Polycarbonate plastic } \\
\text { Canned food } \\
\text { Sport bottles } \\
\text { Thermal receipt paper } \\
\text { Children's toys }\end{array}$ \\
\hline & $\begin{array}{l}\text { Parabens, Triclosan, } \\
\text { Benzophenone-3 }\end{array}$ & $\begin{array}{l}\text { Cosmetics } \\
\text { Toothpaste } \\
\text { Sunscreen } \\
\text { Perfumes } \\
\text { Pharmaceutical products } \\
\text { Detergents } \\
\text { Soaps } \\
\text { Plastic packaging } \\
\text { Textiles }\end{array}$ \\
\hline & Phthalates & $\begin{array}{l}\text { Polyvinyl chloride (PVC) plastics } \\
\text { Vinyl building products } \\
\text { Adhesives } \\
\text { Fragrances } \\
\text { Medical equipment } \\
\text { Detergents }\end{array}$ \\
\hline & Currently used pesticides & $\begin{array}{l}\text { Agriculture } \\
\text { Residential settings }\end{array}$ \\
\hline
\end{tabular}

Source ${ }^{101}$.

in the European Union in the early $80 \mathrm{~s}^{30}$. Due to the strong evidence of the adverse health effects of other OCs, these compounds were internationally banned at the Stockholm Convention in 200131. However, they can bioaccumulate and persist in the environment for long periods. They have long biological half-lives that can range from several years to decades in some compounds ${ }^{32}$. Currently, the main source of exposure to OCs is diet. Biomonitoring studies show that current populations are exposed to these substances finding detectable levels in blood samples ${ }^{18}$ (Table 1).
OCs may interfere in the lung morphogenesis as well as play a role in inflammation processes both pre- and postnatally. These compounds are endocrine disruptors with estrogenic and anti-androgenic properties ${ }^{33}$. Therefore, they may interact with oestrogenic and androgenic receptors and alter the related signalling pathways, including the activation of the AhR pathway, which has been shown to delay lung development in animal studies $^{34}$. Furthermore, exposure to OCs has also been related to inflammation, observing increased interleukins and immunoglobulins in children exposed to them ${ }^{35-37}$. 
TABLE 3. Studies on persistent organic pollutants and lung function by year of publication

\begin{tabular}{|c|c|c|c|c|c|c|c|}
\hline Pollutant & $\begin{array}{l}\text { Author } \\
\text { (year) }\end{array}$ & $\begin{array}{l}\text { Country, } \\
\text { study design } \\
\text { (cohort name) }\end{array}$ & $\mathbf{N}$ & $\begin{array}{c}\text { Year of } \\
\text { recruitment }\end{array}$ & $\begin{array}{l}\text { Outcome } \\
\text { age }\end{array}$ & $\begin{array}{l}\text { Exposure } \\
\text { assessment }\end{array}$ & $\begin{array}{l}\text { Statistically significant main } \\
\text { findings }\end{array}$ \\
\hline \multirow[t]{3}{*}{$\begin{array}{l}\text { Organochlorine } \\
\text { compounds }\end{array}$} & $\begin{array}{l}\text { Hansen et } \\
\text { al. }(2016)^{38}\end{array}$ & $\begin{array}{l}\text { Denmark, birth } \\
\text { cohort } \\
\text { (Danish Fetal } \\
\text { Origins Birth } \\
\text { Cohort) }\end{array}$ & 414 & 1988-1989 & $20 y$ & $\begin{array}{l}\text { Blood } \\
\text { (pregnancy) }\end{array}$ & $\begin{array}{l}\text { OCs - Airway obstruction: } \\
\text { PCBs OR }=2.96(1.14 \text { to } 7.70)^{\mathrm{a}} \\
\text { HCB OR }=2.63(1.07 \text { to } 6.46)^{\mathrm{a}} \\
\text { DDE OR }=2.87(1.09 \text { to } 7.57)^{\mathrm{a}}\end{array}$ \\
\hline & $\begin{array}{l}\text { Abellan et } \\
\text { al. }(2019)^{39}\end{array}$ & $\begin{array}{l}\text { Spain, birth } \\
\text { cohort } \\
\text { (INMA) }\end{array}$ & 1308 & 2004-2008 & $4 y$ and $7 y$ & $\begin{array}{l}\text { Blood } \\
\text { (pregnancy/ } \\
\text { birth) }\end{array}$ & $\begin{array}{l}\text { DDE - FEV }{ }_{1} 4 y: \beta=-53.61(-89.87 \text { to } \\
-17.35)^{\mathrm{b}} ; \mathrm{FEV}_{1} 7 \mathrm{y}: \beta=-36.07(-65.21 \\
\text { to }-6.92)^{\mathrm{c}} ; \mathrm{FVC} 7 \mathrm{y} \beta=-39.45 \mathrm{~mL} \\
(-71.23 \text { to }-7.66)^{\mathrm{c}} \\
\text { HCB }- \text { FVC 7y: } \beta=-56.68(-89.87 \text { to } \\
-23.49)^{\mathrm{c}}\end{array}$ \\
\hline & $\begin{array}{l}\text { Agier et al. } \\
(2019)^{41}\end{array}$ & $\begin{array}{l}6 \text { EU countries, } \\
\text { birth cohort } \\
\text { (HELIX) }\end{array}$ & 1033 & 2003-2009 & $6-12 y$ & $\begin{array}{l}\text { Blood } \\
\text { (pregnancy) }\end{array}$ & None \\
\hline \multirow[t]{3}{*}{$\begin{array}{l}\text { Perfluoroalkyl } \\
\text { substances }\end{array}$} & $\begin{array}{l}\text { Impinen et } \\
\text { al. }(2018)^{49}\end{array}$ & $\begin{array}{l}\text { Norway, birth } \\
\text { cohort (ECA) }\end{array}$ & 641 & 1992-1993 & Birth & Blood (birth) & None \\
\hline & $\begin{array}{l}\text { Agier et al. } \\
(2019)^{41}\end{array}$ & $\begin{array}{l}6 \text { EU countries, } \\
\text { birth cohort } \\
\text { (HELIX) }\end{array}$ & 1033 & 2003-2009 & $6-12 y$ & $\begin{array}{l}\text { Blood } \\
\text { (pregnancy) }\end{array}$ & $\begin{array}{l}\text { PFOA - FEV } 1: \beta=-1.4(-2.7 \text { to }-0.1)^{d} \\
\text { PFNA - FEV } 1: \beta=-1.4(-2.7 \text { to }-0.1)^{d}\end{array}$ \\
\hline & $\begin{array}{l}\text { Manzano- } \\
\text { Salgado et } \\
\text { al. }(2019)^{50}\end{array}$ & $\begin{array}{l}\text { Spain, birth } \\
\text { cohort } \\
\text { (INMA) }\end{array}$ & 992 & $2003-2008$ & $4 y$ and $7 y$ & $\begin{array}{l}\text { Plasma } \\
\text { (pregnancy) }\end{array}$ & $\begin{array}{l}\text { PFOA - FVC 4y: } \beta=-0.17(-0.34 \text { to } \\
-0.01)^{\mathrm{e}}\end{array}$ \\
\hline
\end{tabular}

${ }^{a}$ Coefficient estimates are Odds Ratios of airway obstruction (FEV $/ / F V C<75 \%$ ) given on the third versus the first (lowest) quartile of exposure. ${ }^{b}$ Coefficient estimates are given for a change in $\mathrm{FEV}_{1}(\mathrm{ml})$ on the third versus the first (lowest) quartile of exposure. ${ }^{\circ}$ Coefficient estimates are given for a change in FEV ${ }_{1}$ or FVC (ml) on the second versus the first (lowest) quartile of exposure. ${ }^{d}$ Coefficient estimates are given for a change in mean $\mathrm{FEV}_{1} \%$ for an interquartile range change in PFASs concentration. ${ }^{\text {e}}$ Coefficient estimates are given for a change in FVC z-score for each doubling of PFASs concentration.

DDE: dichlorodiphenyldichloroethylene; ECA: The Environment and Childhood Asthma; FEV 1 : forced expiratory volume in one second; FVC: forced vital capacity; HCB: hexachlorobenzene; HELIX: Human Early-Life Exposome; INMA: INfancia y Medio Ambiente (Environment and Childhood); OCs: organochlorine compounds; PCBs: polychlorinated biphenyl; PFASs: perfluoroalkyl substances; PFNA: perfluorononanoate; PFOA: perfluorooctanoate; y: years.

Current evidence suggests that prenatal exposure to OCs is associated with reduced lung function in the offspring (Table 3). Prenatal exposure to very high levels of DDE, HCB, and PCBs was associated with increased risk of airway obstruction at 20 years of age in a Danish birth cohort established in the $80 \mathrm{~s}^{38}$. In a recent study from a Spanish birth cohort, prenatal exposure to DDE was associated with lower lung function at 4 and 7 years of age, even at low exposure levels. In this study they also observed reduced forced vital capacity (FVC) at certain exposure levels of HCB and found inconsistent results with $\mathrm{PCBs}^{39}$. Recently, in a study assessing the effects of the "exposome" - the totality of environmental exposures from conception onwards ${ }^{40}$ - on lung function, DDT and DDE tended to be associated with reduced $\mathrm{FEV}_{1}$ in school-age children, but results did not reach statistical significance ${ }^{41}$.

\section{Perfluoroalkyl substances}

PFASs are synthetic fluorinated organic compounds produced in large quantities since the 
1950s. PFASs have been widely used as surfactants in industrial and commercial products including paper, textile, and leather coatings, fire-fighting foams, lubricants, and photography industry ${ }^{28}$ (Table 2). Perfluorooctane sulfonate (PFOS) and perfluorooctanoate (PFOA) are the most common PFASs and are widely detected in the environment (i.e. water) ${ }^{42}$ and in human blood ${ }^{17}$ (Table 1). Although they are not stored in the adipose tissue, they are classified as persistent organic pollutants because they form chemical adducts with liver and serum proteins (e.g. albumin) and have long biological half-lives in humans (3-5 years) ${ }^{43}$. PFASs can also cross the placental barrier ${ }^{44}$.

Studies assessing the levels of PFASs in different organs in mice and humans, observed the highest levels in lungs ${ }^{45,46}$, suggesting the lung to be a target of PFASs toxicity. Indeed, new-born rats prenatally exposed to PFASs had retarded lung maturation, namely diminished alveolar airspace and increased alveolar thickness ${ }^{47}$. PFASs are synthetic surfactant molecules and therefore, have the potential to interfere with the integrity of the surface-active interfacial films formed by natural surfactant in the alveolar space. A recent in vitro study showed that PFASs can inhibit lung surfactant function and also induce a pro-inflammatory response in human bronchial epithelial cells ${ }^{48}$.

Up to now, three prospective studies in humans have evaluated whether prenatal exposure to PFASs impairs lung function in the offspring (Table 3). Impinen et al. (2018) ${ }^{49} \mathrm{did}$ not find any association between exposure to PFASs during pregnancy and lung function at birth. In the first exposome study, in utero exposure to PFOA and perfluorononanoate (PFNA) was associated with reduced $\mathrm{FEV}_{1}$ in children aged 6-12 years ${ }^{41}$. In a recent study in the Environment and Childhood - INfancia y Medio Ambiente (INMA) cohort, although authors observed a reduction in FVC at 4 years associated with prenatal exposure to PFOA, this association disappeared after applying a more stringent reproducibility criterion for the spirometry test ${ }^{50}$.

\section{NON-PERSISTENT ORGANIC POLLUTANTS AND LUNG FUNCTION}

\section{Bisphenols}

Bisphenols are widely present in daily life products such as plastic packaging, children's toys, thermal paper, and canned food (Table 2). The general population is continuously exposed to them through dermal contact, inhalation or ingestion. Bisphenol A (BPA) is the most produced bisphenol and has been found in $>90 \%$ of urine samples in general population $^{51,52}$ (Table 1). It has been related to adverse health effects (e.g., metabolic and reproductive disorders, behavioural problems) and in 2017 it was considered a "substance of very high concern" by the European Chemical Agency ${ }^{53}$. Its production and use have been prohibited in some products and in some countries, giving rise to the production of substitute products of similar structure such as bisphenol $S$ (BPS) and bisphenol F (BPF) ${ }^{54}$. After exposure, bisphenols are rapidly excreted from the body (half-life of less than 6 hours).

Bisphenols might interfere in the developing lung thanks to their capacity to cross the placental barrier and the ubiquitous daily 
exposure after birth. A study in mice observed that exposure to BPA during gestation severely retarded foetal lung maturation ${ }^{55}$. This immaturity was characterized by diminished alveolar airspace and thickened septa and by a diminished number of type I pneumocytes ${ }^{55}$. Bisphenols can also induce oxidative stress, endocrine disruption and mitochondrial dysfunction ${ }^{56-58}$. These chemicals can alter inflammatory responses through different signalling pathways. They can activate the reactive oxygen species (ROS) pathway and the mitogen-activated protein $\mathrm{ki}$ nase (MAPK) signalling pathways that lead to DNA damage and cellular death. Bisphenols might also alter immune responses by the stimulation of pro-inflammatory cytokines and the inhibition of anti-inflammatory cytokines production ${ }^{59}$.

Current evidence suggests that BPA exposure increases the risk of respiratory symptoms (reviewed by Vrijheid et al, 2016 ${ }^{60}$ ) but there is limited evidence on the effects of BPA and their substitutes on lung function (Table 4). A study observed that increasing maternal urinary BPA levels were associated with 14.2\% (95\% CI: -24.5, -3.9) decrease in the \% predicted $\mathrm{FEV}_{1}$ at 4 years of age but did not see such association at 5 years ${ }^{61}$. In the Étude des déterminants pré et postnatals du développement de la santé de l'enfant (EDEN) birth cohort study, no association was observed between prenatal BPA levels and predicted $\mathrm{FEV}_{1}$ at 5 years $^{62}$. No association was observed in the Human Early-Life Exposome (HELIX) cohorts between prenatal BPA levels and lung function in school-age children in the first exposome study ${ }^{41}$. Recently, Berger et al. (2020) ${ }^{63}$ assessed the effects of prenatal exposure to 20 endocrine disruptors at the same time, including BPA, on lung function at 7 years. By using the Bayesian Kernel Machine Regression (BKMR), a statistical tool that allows the identification of the most relevant group and pollutant within the group associated with a specific outcome, the authors did not observe any association between BPA and lung function ${ }^{63}$. These findings were previously observed in the same cohort in a study assessing BPA and eight phthalates ${ }^{73}$. We should consider that all previous studies have used one or two spot urines, which, due to the high temporal variability of bisphenols and their short half-lives, might have led to exposure misclassification that biases the associations towards the null.

\section{Parabens, Triclosan, and Benzophenones}

Parabens, triclosan, and benzophenones belong to the chemical group of phenols. Parabens have bactericide and fungicide properties, and they are used in the cosmetic and pharmaceutical industry (Table 2). Triclosan is an antibacterial agent and preservative in detergents and personal care products. Benzophenones act as filters for ultraviolet radiation and are present in sunscreens, perfumes, soaps, and plastic packaging. Human exposure to these chemicals is widespread ${ }^{18}$ (Table 1). The most common parabens used are methyl-, ethyl-, propyl-, and butyl-paraben whereas benzophenone-3 (BP-3) is the most used benzophenone.

Experimental studies suggest that parabens, triclosan, and BP-3 lead to reduced lung function through their capacity to link to estrogenic receptor and PPAR ${ }^{64}$. For 
TABLE 4. Studies on non-persistent organic pollutants and lung function by year of publication

\begin{tabular}{|c|c|c|c|c|c|c|c|}
\hline Pollutant & $\begin{array}{l}\text { Author, } \\
\text { Year }\end{array}$ & $\begin{array}{l}\text { Country, study } \\
\text { design (cohort } \\
\text { name) }\end{array}$ & $\mathbf{N}$ & $\begin{array}{l}\text { Year of } \\
\text { recruitment }\end{array}$ & $\begin{array}{l}\text { Outcome } \\
\text { age }\end{array}$ & $\begin{array}{l}\text { Exposure } \\
\text { assessment }\end{array}$ & $\begin{array}{l}\text { Statistically } \\
\text { significant main } \\
\text { findings }\end{array}$ \\
\hline \multirow[t]{5}{*}{ Bisphenols } & $\begin{array}{l}\text { Spanier et } \\
\text { al. }(2014)^{61}\end{array}$ & $\begin{array}{l}\text { US, birth cohort } \\
\text { (HOME) }\end{array}$ & 208 & $2003-2006$ & $4-5 y$ & $\begin{array}{l}2 \text { urines } \\
\text { (pregnancy) }\end{array}$ & $\begin{array}{l}\text { BPA - FEV } 14 \text { : } \\
\beta=-14.2 \\
(-24.5 \text { to }-3.90)^{\text {a }}\end{array}$ \\
\hline & $\begin{array}{l}\text { Vernet et al. } \\
(2017)^{62}\end{array}$ & $\begin{array}{l}\text { France, birth cohort } \\
\text { (EDEN) }\end{array}$ & 228 & $2002-2006$ & $5 y$ & 1 urine (pregnancy) & None \\
\hline & $\begin{array}{l}\text { Berger et al. } \\
(2019)^{69, b}\end{array}$ & $\begin{array}{l}\text { US, birth cohort } \\
\text { (CHAMACOS) }\end{array}$ & 260 & $1999-2000$ & $7 y$ & $\begin{array}{l}2 \text { urines } \\
\quad \text { (pregnancy) }\end{array}$ & None \\
\hline & $\begin{array}{l}\text { Agier et al. } \\
(2019)^{41}\end{array}$ & $\begin{array}{l}6 \text { EU countries, birth } \\
\text { cohort (HELIX) }\end{array}$ & 1,033 & 2003-2009 & $6-12 y$ & $\begin{array}{l}1 \text { urine (pregnancy } \\
\text { and childhood) }\end{array}$ & None \\
\hline & $\begin{array}{l}\text { Berger et al. } \\
(2020)^{63, b}\end{array}$ & $\begin{array}{l}\text { US, birth cohort } \\
\text { (CHAMACOS) }\end{array}$ & 282 & $1999-2000$ & $7 y$ & $\begin{array}{l}2 \text { urines } \\
\text { (pregnancy) }\end{array}$ & None \\
\hline \multirow{4}{*}{$\begin{array}{l}\text { Parabens, } \\
\text { Triclosan, } \\
\text { Benzophenones }\end{array}$} & $\begin{array}{l}\text { Vernet et al. } \\
(2017)^{62}\end{array}$ & $\begin{array}{l}\text { France, birth cohort } \\
\text { (EDEN) }\end{array}$ & 228 & $2002-2006$ & $5 y$ & 1 urine (pregnancy) & None \\
\hline & $\begin{array}{l}\text { Berger et al. } \\
(2018)^{69, b}\end{array}$ & $\begin{array}{l}\text { US, birth cohort } \\
\text { (CHAMACOS) }\end{array}$ & 296 & $1999-2000$ & $7 y$ & 2 urine (pregnancy) & None \\
\hline & $\begin{array}{l}\text { Agier et al. } \\
(2019)^{41}\end{array}$ & $\begin{array}{l}6 \text { EU countries, birth } \\
\text { cohort (HELIX) }\end{array}$ & 1,033 & $2003-2009$ & $6-12 y$ & $\begin{array}{l}1 \text { urine (pregnancy } \\
\text { and childhood) }\end{array}$ & None \\
\hline & $\begin{array}{l}\text { Berger et al. } \\
(2020)^{63, b}\end{array}$ & $\begin{array}{l}\text { US, birth cohort } \\
\text { (CHAMACOS) }\end{array}$ & 282 & $1999-2000$ & $7 y$ & $\begin{array}{l}2 \text { urines } \\
\text { (pregnancy) }\end{array}$ & None \\
\hline \multirow[t]{5}{*}{ Phthalates } & $\begin{array}{l}\text { Vernet et al. } \\
(2017)^{62}\end{array}$ & $\begin{array}{l}\text { France, birth cohort } \\
\text { (EDEN) }\end{array}$ & 228 & $2002-2006$ & $5 y$ & 1 urine (pregnancy) & None \\
\hline & $\begin{array}{l}\text { Berger et al. } \\
(2018)^{69, b}\end{array}$ & $\begin{array}{l}\text { US, birth cohort } \\
\text { (CHAMACOS) }\end{array}$ & 296 & $1999-2000$ & $7 y$ & $\begin{array}{l}2 \text { urines } \\
\text { (pregnancy) }\end{array}$ & $\begin{array}{l}\text { MEP - } \text { FEF }_{25-75}: \\
\beta=-3.22 \\
(-6.02 \text { to }-0.34)^{c}\end{array}$ \\
\hline & $\begin{array}{l}\text { Berger et al. } \\
(2019)^{74, b}\end{array}$ & $\begin{array}{l}\text { US, birth cohort } \\
\text { (CHAMACOS) }\end{array}$ & 260 & $1999-2000$ & $7 y$ & $\begin{array}{l}2 \text { urines } \\
\quad \text { (pregnancy) }\end{array}$ & $\begin{array}{l}\text { MCOP }-\mathrm{FEV}_{1}: \beta=-0.09 \\
(-0.15 \text { to }-0.03)^{\mathrm{c}} ; \\
\text { FEF }_{25-75}: \beta=-7.06 \\
(-11.04 \text { to }-2.90)^{\mathrm{c}}\end{array}$ \\
\hline & $\begin{array}{l}\text { Agier et al. } \\
(2019)^{41}\end{array}$ & $\begin{array}{l}6 \text { EU countries, birth } \\
\text { cohort (HELIX) }\end{array}$ & 1,033 & 2003-2009 & $6-12 y$ & $\begin{array}{l}1 \text { urine (pregnancy } \\
\text { and childhood) }\end{array}$ & None \\
\hline & $\begin{array}{l}\text { Berger et al. } \\
(2020)^{63, \mathrm{~b}}\end{array}$ & $\begin{array}{l}\text { US, birth cohort } \\
\text { (CHAMACOS) }\end{array}$ & 282 & $1999-2000$ & $7 y$ & $\begin{array}{l}2 \text { urines } \\
\text { (pregnancy) }\end{array}$ & $\begin{array}{l}\text { MCOP - FEV }: \\
P I P=-0.07(0.05)^{d}\end{array}$ \\
\hline \multirow[t]{2}{*}{$\begin{array}{l}\text { Currently used } \\
\text { pesticides }\end{array}$} & $\begin{array}{l}\text { Raanan et } \\
\text { al. }(2017)^{81}\end{array}$ & $\begin{array}{l}\text { US, birth cohort } \\
\text { (CHAMACOS) }\end{array}$ & 279 & $1999-2000$ & $7 y$ & $\begin{array}{l}2 \text { urines } \\
\text { (pregnancy), } 5 \\
\text { urines (childhood) }\end{array}$ & None \\
\hline & $\begin{array}{l}\text { Agier et al. } \\
(2019)^{41}\end{array}$ & $\begin{array}{l}6 \text { EU countries, birth } \\
\text { cohort (HELIX) }\end{array}$ & 1,033 & 2003-2009 & $6-12 y$ & $\begin{array}{l}1 \text { urine (pregnancy } \\
\text { and childhood) }\end{array}$ & None \\
\hline
\end{tabular}

${ }^{a}$ Coefficient estimates are given for a change in FEV $\%$ for every 10 -fold increase in the mean BPA concentration. ${ }^{b}$ In Berger et al. ${ }^{69}$ three phthalates were assessed together with three parabens and four phenols; in Berger et al. ${ }^{74}$ eight phthalates were assessed together with BPA; in Berger et al. ${ }^{63}$ eleven phthalates were assessed together with four parabens and five phenols. 'Coefficient estimates are given for a change in $\mathrm{L}_{\mathrm{s}}$ of $\mathrm{FEF}_{25-75}$ percent difference or $\mathrm{L}_{\text {of }} \mathrm{FEV} \mathrm{V}_{1}$ for each doubling of phthalates concentration. dPredicted probability and standard deviation obtained in the Bayesian Kernel Regression Model for an interquartile range change in phthalates concentration.

BPA: bisphenol A; DAPs: dialkyl phosphate metabolites; DEHP: di-(2-ethylhexyl) phthalate; Développement et de la Santé de l'Enfant; EDEN: Étude des déterminants pré et postnatals du développement de la santé de l'enfant; $\mathrm{FEF}_{25-75}$ : forced expiratory flow at $25-75 \%$ of FVC; FEV capacity; HELIX: Human Early-Life Exposome; HOME: Health Outcomes and Measures of the Environment; MCOP: monocarboxyisooctyl phthalate; MEP: monoethyl phthalate; PIP: posterior inclusion probability; y: years. 
example, studies in rats show that prenatal exposure to BP-3 can impair the expression of estrogenic receptor $-\alpha$ and $-\beta^{65,66}$. Estrogenic receptor- $\beta$ is abundantly expressed and biologically active in the lungs and regulates alveolar formation and surfactant homeostasis 9 . BP-3 may also disrupt the levels of PPAR $\gamma$ receptor, down-regulating surfactant protein expression in alveolar type II cells ${ }^{9}$, essential for lung maturation. Triclosan was shown to decrease the viability, growth and morphology of lung epithelial cells ${ }^{67}$. Parabens, triclosan, and BP-3 can also increase biomarkers of oxidative stress and inflammation ${ }^{68}$.

Four studies in humans have evaluated whether prenatal exposure to parabens, triclosan, and BP-3 can affect lung function in the offspring (Table 4). The French cohort EDEN evaluated exposure to parabens, triclosan, and BP-3 in 228 pregnant women and their male's offspring and observed that exposure to ethyl-paraben was associated with reduced $\mathrm{FEV}_{1}$ at 5 years; however, this association did not reach statistical significance. No association was observed for the other phenols $^{62}$. In 392 pregnant women and their children of the Center for the Health Assessment of Mothers and Children of Salinas (CHAMACOS) cohort, an agricultural community in California, US, Berger et al. (2018) ${ }^{69}$ assessed the association between prenatal exposure to parabens, triclosan, and BP-3 and lung function but did not observe any association. These null results have recently been confirmed in another study in the same cohort evaluating the combined effect of 20 endocrine disruptors on lung function at 7 years $^{63}$. Parabens and BP-3 showed a low contribution in the overall model including eleven phthalates, five phenols, and four parabens; for triclosan, they observed a positive association but in the BKMR model, its importance was low. Finally, in the HELIX cohort, Agier et al. (2019) ${ }^{41}$ did not observe any association between prenatal exposure to ethyl-paraben and lung function at 6-12 years. Prenatal exposure to the other phenols was also not associated with lung function at school age.

\section{Phthalates}

Phthalates are phthalic acid diester compounds commonly used as plasticizers to increase flexibility and transparency of hard polyvinyl chloride (PVC) plastics. Phthalates are divided into long- and short-chain phthalates. The long-chain are the ones used in PVC plastics whereas the short-chain are used in non-PVC products including adhesives and personal care products ${ }^{28}$ (Table 2). Both groups of phthalates are produced in large quantities worldwide and humans are continuously exposed to them through food, cosmetics products, and indoor air ${ }^{28}$. After exposure, they are metabolized and excreted from the body in hours or days. In order to avoid external contamination (e.g., phthalates present in lab plastic material), the metabolites and not their parent compounds are detected in biological samples, preferably in urine.

In vivo studies have shown that exposure to phthalates during gestation can lead to delayed lung maturation in newborn rats. Offspring of rats exposed to the long-chain di-(2-ethylhexyl) phthalate (DEHP) during gestation had increased lung interstitial tissue proportion and diminished number of 
airspace units leading to a reduction of the gas-exchange surface ${ }^{70-72}$. A significant increase in the number and dimension of type-II pneumocytes, responsible for secretion of pulmonary surfactant and implicated in the epithelial repair, was observed ${ }^{71}$. Moreover, an in vitro study showed that exposure to DEHP altered the structure and migration of A549 cells, cell lines used as prototypes of type-II pneumocytes, and the production of pulmonary surfactant ${ }^{73}$.

A total of five studies, three of them from the same cohort, have evaluated this association (Table 4). In the French cohort EDEN, the high molecular weight phthalate monocarboxyisooctyl phthalate (MCOP) and the low molecular weight phthalate mono-isobutyl phthalate (MiBP) tended to be associated with reduced $\mathrm{FEV}_{1} \%$ at 5 years, but associations did not reach statistical significance ${ }^{62}$. A total of three studies have been conducted within the CHAMACOS cohort in the US $63,69,74$. These three studies differ in the number of phthalate metabolites included and the statistical tools used to assess the combined effect. The most consistent finding of these studies was the reduction of $\mathrm{FEV}_{1}$ at 7 years associated with exposure to MCOP, even after accounting for other pollutants. Indeed, the most recent study included three pollutant groups (i.e. phthalates, parabens, and other phenols), and the BKMR model identified the phthalate group, and particularly MCOP, as the most important associated with impaired lung function ${ }^{63}$. Finally, in the HELIX study including a large number of pollutants and other environmental factors, exposure to DEHP metabolites during pregnancy was not associated with lung function at 6-12 years of age ${ }^{41}$.

\section{Currently used pesticides}

Restriction on the use of persistent pesticides such as DDT has led to the use of non-persistent alternatives such as organophosphate pesticides, carbamates, and pyrethroids. They are widely produced and used worldwide for controlling pests in both agricultural and residential settings (Table 2). In 2018, around 400,000 tonnes of pesticides were sold in Europe with the majority used in agriculture ${ }^{75}$. Organophosphate pesticides (e.g., chlorpyrifos, malathion) are the most widely used active substances, followed by pyrethroids and carbamates. Exposure to pesticides is ubiquitous in humans (Table 1), primarily through their diet. However, the detection frequencies in biospecimens are usually low due to the intermittent exposure and their rapid elimination from the body ${ }^{76-78}$.

Organophosphate pesticides can affect lung function by inhibition of the acetylcholinesterase (AChE) enzyme, preventing the metabolism of acetylcholine and consequently increasing bronchoconstriction and mucus secretion. It is also postulated that organophosphate pesticides can produce bronchoconstriction at levels below those needed to inhibit AChE via direct effect on muscarinic receptors; receptors responsible of controlling muscle tone, mucus secretion, vasodilatation, and inflammation ${ }^{79,80}$.

We have identified two studies that evaluated the lung function effects of prenatal exposure to currently used pesticides (Table 4); the two were focused on organophosphate pesticides $^{41,81}$. The first study was conducted in the CHAMACOS cohort. Organophosphate pesticides, particularly six dialkyl phosphate 
TABLE 5. Summary of the effects of in utero exposure to organic pollutants on lung function

\begin{tabular}{|l|c|l|l|}
\hline Pollutants & $\begin{array}{c}\text { Number of studies } \\
\text { Effects observed }\end{array}$ & \multicolumn{1}{|c|}{ Evidence $^{\text {a }}$} \\
\hline Persistent organic pollutants & 3 & $3 \downarrow$ lung function & Insufficient \\
\hline Organochlorine compounds & 3 & $2 \downarrow$ lung function / 1 no effects & Insufficient \\
\hline Perfluoroalkyl substances & & $1 \downarrow$ lung function / 4 no effects & Insufficient \\
\hline Non-persistent organic pollutants & 5 & 4 no effects & Insufficient \\
\hline Bisphenols & 4 & $3 \downarrow$ lung function / 2 no effects & Insufficient \\
\hline Parabens, Triclosan, Benzophenones & 5 & 2 no effects & Insufficient \\
\hline Phthalates & 2 &
\end{tabular}

${ }^{a} G o o d$ evidence: for an association based on consistent results from multiple studies and meta-analyses; Moderate evidence: of an association based on multiple studies, but with some inconsistencies; Insufficient evidence: evidence for an association based on only a few studies, or with substantial inconsistencies; 0 : no or very few studies ${ }^{102}$.

metabolites (DAPs), were measured twice during pregnancy ${ }^{81}$. Prenatal exposure to DAPs was not associated with $\mathrm{FEV}_{1}$ or FVC at 7 years. In the HELIX cohorts, DAPs were also measured during pregnancy but no association was found with lung function at school-age $e^{41}$.

\section{DISCUSSION}

In this review, we provide a broad summary of the current evidence of the effects of prenatal exposure to organic pollutants on lung function in the offspring. Overall, evidence is insufficient for all organic pollutants, with few studies and inconsistent results across them (Table 5). Few studies have found associations and the effects observed (i.e. changes in lung function parameters) are small (e.g., $50 \mathrm{~mL}$ reduction in $\mathrm{FEV}_{1}$ for DDE exposure ${ }^{39}$ ). Inconsistencies across studies may reflect differences in sociodemographic characteristics of the populations, different use of consumer products between countries, measurement error associated with the assessment of the outcome and the exposure, and the statistical approaches used to assess the lung function effects of organic pollutants. Hereby we discuss different possibilities that may explain the inconsistent results across studies.

Outcome measurement: The evidence on the effects of organic pollutants on respiratory health is larger and more consistent in relation to respiratory symptoms (i.e. respiratory tract infections, wheezing, asthma) (reviewed by Vrijheid et al., 2016 ${ }^{60}$ ). More studies have been conducted in this regard because information on respiratory symptoms can be easily obtained from questionnaires administered to the parents. On the contrary, spirometry is not easily conducted in young untrained children participating in population-based studies and needs to be performed by a pulmonologist or trained nurse; however, spirometry offers an objective measurement of lung function less subject to bias than parental administered questionnaires. All the studies included in this review performed spirometry from 4 to 20 years of age except Impinen et al. $(2018)^{49}$ where children performed tidal breathing shortly after birth. Spirometry is a good 
method to measure pulmonary function and the most commonly performed ${ }^{82}$. However, there are other techniques that can be performed to complement or improve the outcome measurement. The reliability of spirometry performance in very young children has been argued. Techniques such as body plethysmography and interrupter resistance technique $\left(\mathrm{R}_{\text {int }}\right)$ can be a good complement or alternative to spirometry testing in younger children, being the latter the most suitable for young children due to its minimal difficulty to be performed ${ }^{83-85}$. In very young children (less than 4 years of age), pulmonary function can be measured with non-invasive techniques that do not require sedation such as multiple-breath washout test, tidal breathing (as did Impinen et al., 2018 ${ }^{49}$ ), and forced oscillation technique ${ }^{3,86,87}$. These techniques are simple to perform, require little cooperation, and provide information on lung development, including its volume and ventilation inhomogeneity (multiple-breath washout), airway size (tidal breathing and forced oscillation), mechanical properties (forced oscillation), respiratory control (tidal breathing), and small airway function (multiple-breath washout and forced oscillation). With these techniques, researchers have been able to detect changes in lung function in relation to prenatal exposure to air pollution ${ }^{86}$. In older children and adults, the reversibility test can be performed to measure airflow limitation. This technique measures lung function performing spirometry before and after the administration of a bronchodilator such as salbutamol. A positive result is given when there is a significant improvement in lung function after the administration of the bronchodilator (change in $\mathrm{FEV}_{1} \geq 12 \%$ or $\geq 200 \mathrm{ml}$ ). It is considered consistent with the diagnosis of asthma and
$\mathrm{COPD}^{88,89}$, although in population studies a positive result cannot discern between asthma and $\mathrm{COPD}^{90}$. The reversibility test is easy to conduct and does not require medical assistance.

Exposure assessment: We have restricted ourselves to articles assessing the levels of organic pollutants in human biospecimens. Studies where exposure to organic pollutants (e.g. pesticides) was estimated by means of residential proximity to a contaminated area (e.g. crops) have not been included (e.g. Raanan et al., 201791). Biomonitoring is the most extensive strategy for the assessment of environmental influences on health because samples are easy to collect, multiple exposures can be measured in the same biospecimen, and levels provide information of exposure for those pollutants found in many sources, as the case of organic pollutants ${ }^{92}$. However, biomarker levels could be subject to physiological distortion (e.g., renal clearance in the case of PFASs), could not reflect the internal dose (more directly related with the health outcome), and in the case of non-persistent pollutants, a single spot urine sample only reflects exposure for a short period of time (leading to exposure misclassification and attenuation of the results). We should consider all these limitations when interpreting the results. Alternatively, physiological conditions can be considered such as the glomerular filtration rate ${ }^{93}$, internal dose can be estimated by using physiologically based pharmacokinetic modelling (PBPK) ${ }^{94}$, and multiple samples per subject can be collected to obtain information on long-term exposure ${ }^{76,95}$.

Statistical approach: The majority of studies included in this review assessed one pollutant 
at each time. However, humans are exposed to multiple organic pollutants at the same time. In the last decade, the exposome approach has been proposed as a new to paradigm to encompass the totality of human environmental (meaning all non-genetic) exposures from conception onwards, complementing the genome ${ }^{96}$. Some of the studies included in this review have already developed multipollutant models with the aim to identify the most relevant pollutant associated with lung function ${ }^{41,63,69,74}$. Novel statistical tools are being developed to study chemical mixtures ${ }^{15}$. For the study of the health effects of endocrine disrupting chemicals, these methods should consider non-linear exposure-outcome relationships (lower doses can have more harmful effects than higher dos$\mathrm{es}^{39}$ ) and potential interactions and confounding between pollutants, as the BKMR method used by Berger et al. (2020) ${ }^{63}$ offers.

External validity: Particularly for non-persistent organic pollutants, we should consider that these pollutants have been studied among the same few population-based cohort studies (i.e., in the US: CHAMACOS; and in Europe: HELIX, EDEN, INMA), thus, limiting the generalization of the results in other population settings with different use of chemicals (and in consequence different exposure levels) and sociodemographic characteristics.

Public health implications: Although the changes in lung function associated with exposure to organic pollutants may not be clinically relevant (e.g. $50 \mathrm{~mL}$ reduction in $\mathrm{FEV}_{1}$ for DDE exposure ${ }^{39}$, as mentioned before), they can be important from an etiological perspective and at a population level. A good example to illustrate the societal impact of small effects associated with exposure to environmental pollutants is the case of lead exposure in children and the reduction of intelligence quotient (IQ) of 6 points ${ }^{97,98}$. It is estimated that an average drop of 6 points in IQ across the population would nearly double the number of people with an IQ below $70^{99}$. Therefore, when there is absence of consistent evidence about the health effects of a given exposure, such as the association of organic pollutants with lung function, the precautionary principle should prevail and apply policy measures to reduce its exposure.

\section{CONCLUSION}

In conclusion, although in the last decade the number of studies assessing the lung function effects of prenatal exposure to organic pollutants have increased, the evidence is still limited and inconsistent. Many studies did not find any association; this can reflect a real null effect or methodological limitations such as exposure misclassification, an important challenge of the study of the health effects of non-persistent pollutants, or measurement error of lung function parameters performed at young age. Further studies, with larger sample size to study susceptible groups, conducted in different population settings, with a thoughtful sampling design, and considering multiple pollutants, are needed. In parallel, public health strategies, such as the one that the Federation of Gynecology and Obstetrics, the University of California, and the Health and Environment Alliance has recently launched ${ }^{100}$, are needed to reduce exposure to organic pollutants in the community and particularly in pregnant women. 


\section{FUNDING}

Alicia Abellan holds a LifeCycle fellowship, funded from the European Union's Horizon 2020 research and innovation programme under grant agreement No 733206. Maribel Casas holds a Miguel Servet fellowship (CP16/00128) funded by Instituto de Salud Carlos III and co-funded by European Social Fund "Investing in your future". We acknowledge support from the Spanish Ministry of Science and Innovation through the "Centro de Excelencia Severo Ochoa 2019-2023" Program (2018-000806-S), and support from the Generalitat de Catalunya through the CERCA Program.

\section{DISCLOSURES}

\author{
Dr. Abellan and Dr. Casas have nothing to \\ disclose.
}

\section{REFERENCES}

1. Stern DA, Morgan WJ, Wright AL, Guerra S, Martinez FD. Poor airway function in early infancy and lung function by age 22 years: a non-selective longitudinal cohort study. Lancet. 2007;370:758-64.

2. Berry $\mathrm{CE}$, Billheimer $\mathrm{D}$, Jenkins IC et al. A distinct low lung function trajectory from childhood to the fourth decade of life. Am J Respir Crit Care Med. 2016;194:607-12.

3. Håland G, Carlsen KCL, Sandvik L et al. Reduced lung function at birth and the risk of asthma at 10 years of age. N Engl J Med. 2006;355:1682-9.

4. Bui DS, Lodge CJ, Burgess JA et al. Childhood predictors of lung function trajectories and future COPD risk: a prospective cohort study from the first to the sixth decade of life. Lancet Respir Med. 2018;6:535-44.

5. Vos T, Allen C, Arora M et al. Global, regional, and national incidence, prevalence, and years lived with disability for 310 diseases and injuries, 1990-2015: a systematic analysis for the Global Burden of Disease Study 2015. Lancet. 2016;388:1545-1602.

6. Martinez FD. Early-Life Origins of Chronic Obstructive Pulmonary Disease. Drazen JM, ed. N Engl J Med. 2016;375:871-8.

7. Postma DS, Bush A, Van Den Berge M. Risk factors and early origins of chronic obstructive pulmonary disease. Lancet. 2015;385:899-909.

8. Hanson M, Gluckman P. Developmental origins of noncommunicable disease: Population and public health implications. Am J Clin Nutr. 2011;94.

9. Miller MD, Marty MA. Impact of environmental chemicals on lung development. Environ Health Perspect. 2010;118:1155-64.
10. Vardavas CI, Hohmann C, Patelarou E et al. The independent role of prenatal and postnatal exposure to active and passive smoking on the development of early wheeze in children. Eur Respir J. 2016;48:115-24.

11. Bascom R, Bromberg PA, Costa DA et al. Health effects of outdoor air pollution. Am J Respir Crit Care Med. 1996;153:3-50.

12. Gehring U, Wijga AH, Hoek G et al. Exposure to air pollution and development of asthma and rhinoconjunctivitis throughout childhood and adolescence: A population-based birth cohort study. Lancet Respir Med. 2015; 3:933-42.

13. La Merrill MA, Vandenberg LN, Smith MT et al. Consensus on the key characteristics of endocrine-disrupting chemicals as a basis for hazard identification. Nat Rev Endocrinol. 2020;16:45-57.

14. Search the TEDX List - The Endocrine Disruption Exchange. Available at: https://endocrinedisruption.org/interactive-tools/tedx-list-of-potential-endocrine-disruptors/search-the-tedx-list. Accessed August 28, 2020.

15. Lazarevic N, Barnett AG, Sly PD, Knibbs LD. Statistical Methodology in Studies of Prenatal Exposure to Mixtures of Endocrine-Disrupting Chemicals: A Review of Existing Approaches and New Alternatives. Environ Health Perspect. 2019;127:026001.

16. Koppen G, Den Hond E, Nelen V et al. Organochlorine and heavy metals in newborns: Results from the Flemish Environment and Health Survey (FLEHS 2002-2006). Environ Int. 2009;35:1015-22.

17. Fei C, McLaughlin JK, Tarone RE, Olsen J. Perfluorinated chemicals and fetal growth: A study within the Danish national birth cohort. Environ Health Perspect. 2007;115:1677-82.

18. Haug LS, Sakhi AK, Cequier E et al. In-utero and childhood chemical exposome in six European mother-child cohorts. Environ Int. 2018;121: 751-63.

19. Trasande L, Zoeller RT, Hass U et al. Burden of disease and costs of exposure to endocrine disrupting chemicals in the European Union: an updated analysis. Andrology. 2016;4:565-72.

20. Goldenman G, Holland M, Lietzmann J, Meura L. Study for the Strategy for a Non-Toxic Environment of the 7th Environment Action Programme Final Report. Eur Comm. 2017.

21. Kajekar R. Environmental factors and developmental outcomes in the lung. Pharmacol Ther. 2007;114:129-45.

22. McGeachie MJ, Yates KP, Zhou X et al. Patterns of Growth and Decline in Lung Function in Persistent Childhood Asthma. N Engl J Med. 2016;374: $1842-52$

23. Bizzarro MJ, Gross I. Effects of hormones on fetal lung development. Obstet Gynecol Clin North Am. 2004;31:949-61.

24. Mendelson CR, Boggaram V. Hormonal control of the surfactant system in fetal lung. Annu Rev Physiol. 1991;53:415-40.

25. Zhang J, Yang Y, Liu W, Schlenk D, Liu J. Glucocorticoid and mineralocorticoid receptors and corticosteroid homeostasis are potential targets for endocrine-disrupting chemicals. Environ Int. 2019;133.

26. Medjakovic S, Zoechling A, Gerster P et al. Effect of nonpersistent pesticides on estrogen receptor, androgen receptor, and aryl hydrocarbon receptor. Environ Toxicol. 2014;29:1201-16.

27. Gore AC, Chappell VA, Fenton SE et al. Executive Summary to EDC-2: The Endocrine Society's second Scientific Statement on endocrine-disrupting chemicals. Endocr Rev. 2015;36:593-602.

28. Casals-Casas C, Desvergne B. Endocrine disruptors: From endocrine to metabolic disruption. Annu Rev Physiol. 2011;73:135-62.

29. United States Environmental Protection Agency. DDT - A Brief History and Status. United States Environ Prot Agency. 2016 Available at: https:/ / www. epa.gov/ingredients-used-pesticide-products/ddt-brief-history-and-status. Accessed February 21, 2017.

30. European Commission. Presence of persistent chemicals in the human body results of Commissioner Wallstrom's blood test. Eur Comm. 2003.

31. United Nations Environment Programme (UNEP). Report of the Conference of the Parties to the Stockholm Convention on Persistent Organic Pollutants on the Work of Its Eighth Meeting. Geneva; 2017. 
32. Porta M, Puigdomènech E, Ballester F et al. Monitoring concentrations of persistent organic pollutants in the general population: The international experience. Environ Int. 2008;34:546-61.

33. Shanle EK, Xu W. Endocrine disrupting chemicals targeting estrogen receptor signaling: identification and mechanisms of action. Chem Res Toxicol. 2011;24:6-19.

34. Kransler KM, McGarrigle BP, Swartz DD, Olson JR. Lung Development in the Holtzman Rat is Adversely Affected by Gestational Exposure to 2,3,7,8-Tetrachlorodibenzo-p-Dioxin. Toxicol Sci. 2009;107:498-511.

35. Brooks K, Hasan H, Samineni S, Gangur V, Karmaus W. Placental p,p'-dichlorodiphenyldichloroethylene and cord blood immune markers. Pediatr Allergy Immunol. 2007;18:621-24.

36. Gascon M, Sunyer J, Martínez D et al. Persistent organic pollutants and children's respiratory health: The role of cytokines and inflammatory biomarkers. Environ Int. 2014;69:133-140.

37. Karmaus W, Brooks KR, Nebe T, Witten J, Obi-Osius N, Kruse H. Immune function biomarkers in children exposed to lead and organochlorine compounds: a cross-sectional study. Environ Health. 2005;4:5.

38. Hansen S, Strøm M, Olsen SF et al. Prenatal exposure to persistent organic pollutants and offspring allergic sensitization and lung function at 20 years of age. Clin Exp Allergy. 2016;46:329-36.

39. Abellan A, Sunyer J, Garcia-Esteban R et al. Prenatal exposure to organochlorine compounds and lung function during childhood. Environ Int. 2019;131:105049.

40. Vrijheid M. The exposome: A new paradigm to study the impact of environment on health. Thorax. 2014;69:876-8.

41. Agier L, Basagaña X, Maitre L et al. Early-life exposome and lung function in children in Europe: an analysis of data from the longitudinal, population-based HELIX cohort. Lancet Planet Heal. 2019;3:e81-e92.

42. Domingo JL, Nadal M. Human exposure to per- and polyfluoroalkyl substances (PFAS) through drinking water: A review of the recent scientific literature. Environ Res. 2019;177.

43. Olsen GW, Mair DC, Lange CC et al. Per- and polyfluoroalkyl substances (PFAS) in American Red Cross adult blood donors, 2000-2015. Environ Res. 2017;157:87-95

44. Manzano-Salgado CB, Casas M, Lopez-Espinosa M-J et al. Transfer of perfluoroalkyl substances from mother to fetus in a Spanish birth cohort. Environ Res. 2015;142:471-8.

45. Borg D, Bogdanska J, Sundström M et al. Tissue distribution of 35S-labelled perfluorooctane sulfonate (PFOS) in C57Bl/ 6 mice following late gestational exposure. Reprod Toxicol. 2010;30:558-65.

46. Mamsen LS, Björvang RD, Mucs D et al. Concentrations of perfluoroalkyl substances (PFASs) in human embryonic and fetal organs from first, second, and third trimester pregnancies. Environ Int. 2019;124:482-92.

47. Grasty RC, Bjork JA, Wallace KB, Lau CS, Rogers JM. Effects of prenatal perfluorooctane sulfonate (PFOS) exposure on lung maturation in the perinatal rat. Birth Defects Res Part B Dev Reprod Toxicol. 2005;74:405-16.

48. Sørli JB, Låg M, Ekeren L et al. Per- and polyfluoroalkyl substances (PFASs) modify lung surfactant function and pro-inflammatory responses in human bronchial epithelial cells. Toxicol Vitr. 2020;62.

49. Impinen A, Nygaard UC, Lødrup Carlsen KC et al. Prenatal exposure to perfluoralkyl substances (PFASs) associated with respiratory tract infections but not allergy- and asthma-related health outcomes in childhood. Environ Res. 2018;160:518-23.

50. Manzano-Salgado CB, Granum B, Lopez-Espinosa MJ et al. Prenatal exposure to perfluoroalkyl substances, immune-related outcomes, and lung function in children from a Spanish birth cohort study. Int J Hyg Environ Health. 2019;222:945-54.

51. Ye X, Wong LY, Kramer J, Zhou X, Jia T, Calafat AM. Urinary Concentrations of Bisphenol A and Three Other Bisphenols in Convenience Samples of U.S. Adults during 2000-2014. Environ Sci Technol. 2015;49:11834-9.

52. Calafat AM, Ye X, Wong LY, Reidy JA, Needham LL. Exposure of the U.S. population to Bisphenol A and 4-tertiary-octylphenol: 2003-2004. Environ Health Perspect. 2008;116:39-44.
53. European Chemical Agency. Bisfenol A - ECHA. 2017 Available at: https:/ / echa.europa.eu/es/hot-topics/bisphenol-a. Accessed August 29, 2020.

54. Lehmler HJ, Liu B, Gadogbe M, Bao W. Exposure to Bisphenol A, Bisphenol F, and Bisphenol S in U.S. Adults and Children: The National Health and Nutrition Examination Survey 2013-2014. ACS Omega. 2018;3:6523-32.

55. Hijazi A, Guan H, Cernea M, Yang K. Prenatal exposure to bisphenol A disrupts mouse fetal lung development. FASEB J. 2015;29:4968-77.

56. Khan S, Beigh S, Chaudhari BP et al. Mitochondrial dysfunction induced by Bisphenol A is a factor of its hepatotoxicity in rats. Environ Toxicol. 2016;31:1922-34.

57. Song S, Zhang L, Zhang H, Wei W, Jia L. Perinatal BPA Exposure Induces Hyperglycemia, Oxidative Stress and Decreased Adiponectin Production in Later Life of Male Rat Offspring. Int J Environ Res Public Health. 2014 11:3728-42.

58. Yang YJ, Hong YC, Oh SY et al. Bisphenol A exposure is associated with oxidative stress and inflammation in postmenopausal women. Environ Res. 2009;109:797-801.

59. Kim JJ, Kumar S, Kumar V, Lee YM, Kim YS, Kumar V. Bisphenols as a legacy pollutant, and their effects on organ vulnerability. Int J Environ Res Public Health. 2020;17.

60. Vrijheid M, Casas M, Gascon M, Valvi D, Nieuwenhuijsen M. Environmental pollutants and child health-A review of recent concerns. Int J Hyg Environ Health. 2016;219:331-42.

61. Spanier AJ, Kahn RS, Kunselman AR et al. Bisphenol A Exposure and the Development of Wheeze and Lung Function in Children Through Age 5 Years. JAMA Pediatr. 2014;168:1131.

62. Vernet C, Pin I, Giorgis-Allemand L et al. In Utero Exposure to Select Phenols and Phthalates and Respiratory Health in Five-Year-Old Boys: A Prospective Study. Environ Health Perspect. 2017;125:097006.

63. Berger K, Coker E, Rauch S et al. Prenatal phthalate, paraben, and phenol exposure and childhood allergic and respiratory outcomes: Evaluating exposure to chemical mixtures. Sci Total Environ. 2020;725:138418.

64. Nowak K, Ratajczak-Wrona W, Górska M, Jabłońska E. Parabens and their effects on the endocrine system. Mol Cell Endocrinol. 2018;474:238-51.

65. Schlecht C, Klammer H, Jarry H, Wuttke W. Effects of estradiol, benzophenone- 2 and benzophenone- 3 on the expression pattern of the estrogen receptors (ER) alpha and beta, the estrogen receptor-related receptor 1 (ERR1) and the aryl hydrocarbon receptor (AhR) in adult ovariectomized rats. In: Toxicology.Vol 205. Elsevier; 2004:123-30.

66. Wnuk A, Rzemieniec J, Litwa E, Lason' W, Kajta M. Prenatal exposure to benzophenone-3 (BP-3) induces apoptosis, disrupts estrogen receptor expression and alters the epigenetic status of mouse neurons. J Steroid Biochem Mol Biol. 2018;182:106-18.

67. Kwon JT, Lee M, Seo GB et al. Cytotoxic effects of air freshener biocides in lung epithelial cells. Nat Prod Commun. 2013;8:1301-4.

68. Marshall NB, Lukomska E, Long CM et al. Triclosan induces thymic stromal lymphopoietin in skin promoting Th2 allergic responses. Toxicol Sci. 2015; 147:127-39.

69. Berger K, Eskenazi B, Balmes J, Holland N, Calafat AM, Harley KG. Associations between prenatal maternal urinary concentrations of personal care product chemical biomarkers and childhood respiratory and allergic outcomes in the CHAMACOS study. Environ Int. 2018;121:538-49.

70. Chen SQ, Chen JN, Cai XH et al. Perinatal exposure to di-(2-ethylhexyl) phthalate leads to restricted growth and delayed lung maturation in newborn rats. J Perinat Med. 2010;38:515-21.

71. Magliozzi R, Nardacci R, Scarsella G, Di Carlo V, Stefanini S. Effects of the plasticiser DEHP on lung of newborn rats: Catalase immunocytochemistry and morphometric analysis. Histochem Cell Biol. 2003;120:41-9.

72. Rosicarelli B, Stefanini S. DEHP effects on histology and cell proliferation in lung of newborn rats. Histochem Cell Biol. 2009;131:491-500.

73. Rafael-Vázquez L, García-Trejo S, Aztatzi-Aguilar OG, Bazán-Perkins B, Quintanilla-Vega B. Exposure to diethylhexyl phthalate (DEHP) and monoethylhexyl phthalate (MEHP) promotes the loss of alveolar epithelial phenotype of A549 cells. Toxicol Lett. 2018;294:135-44. 
74. Berger K, Eskenazi B, Balmes J et al. Prenatal high molecular weight phthalates and bisphenol A, and childhood respiratory and allergic outcomes. Pediatr Allergy Immunol. 2019;30:36-46.

75. Pesticide Use in Europe | PAN Europe. Available at: https://www.pan-europe.info/issues/pesticide-use-europe. Accessed August 28, 2020.

76. Casas M, Basagaña X, Sakhi AK et al. Variability of urinary concentrations of non-persistent chemicals in pregnant women and school-aged children. Environ Int. 2018;121:561-73.

77. Llop S, Murcia M, Iñiguez C et al. Distributions and determinants of urinary biomarkers of organophosphate pesticide exposure in a prospective Spanish birth cohort study. Environ Heal A Glob Access Sci Source. 2017;16.

78. Attfield KR, Hughes MD, Spengler JD, Lu C. Within- and between-child variation in repeated urinary pesticide metabolite measurements over a 1-year period. Environ Health Perspect. 2014;122:201-6.

79. Fryer AD, Lein PJ, Howard AS, Yost BL, Beckles RA, Jett DA. Mechanisms of organophosphate insecticide-induced airway hyperreactivity. Am J Physiol - Lung Cell Mol Physiol. 2004;286.

80. Lein PJ, Fryer AD. Organophosphorus insecticides induce airway hyperreactivity by decreasing neuronal M2 muscarinic receptor function independent of acetylcholinesterase inhibition. Toxicol Sci. 2005;83:166-76.

81. Raanan R, Balmes JR, Harley KG et al. Decreased lung function in 7-yearold children with early-life organophosphate exposure. Thorax. 2016;71: 148-153.

82. Graham BL, Steenbruggen I, Barjaktarevic IZ et al. Standardization of spirometry 2019 update an official American Thoracic Society and European Respiratory Society technical statement. Am J Respir Crit Care Med. 2019; 200:E70-E88.

83. Klug B, Bisgaard H. Measurement of the specific airway resistance by plethysmography in young children accompanied by an adult. Eur Respir J. 1997;10.

84. Vilozni D, Efrati O, Hakim F, Adler A, Livnat G, Bentur L. FRC measurements using body plethysmography in young children. Pediatr Pulmonol. 2009;44:885-91.

85. Kaminsky DA. What does airway resistance tell us about lung function? Respir Care. 2012;57:85-99.

86. Latzin P, Röösli M, Huss A, Kuehni CE, Frey U. Air pollution during pregnancy and lung function in newborns: A birth cohort study. Eur Respir J. 2009;33:594-603.

87. Hantos Z, Czövek D, Gyurkovits Z et al. Assessment of respiratory mechanics with forced oscillations in healthy newborns. Pediatr Pulmonol. 2015; 50:344-52.
88. Moeller A, Carlsen KH, Sly PD et al. Monitoring asthma in childhood: Lung function, bronchial responsiveness and inflammation. Eur Respir Rev. 2015; 24:204-5.

89. Pellegrino R, Viegi G, Brusasco V et al. Interpretative strategies for lung function tests. Eur Respir J. 2005;26:948-68.

90. Janson C, Malinovschi A, Amaral AFS et al. Bronchodilator reversibility in asthma and COPD: Findings from three large population studies. Eur Respir J. 2019;54.

91. Raanan R, Gunier RB, Balmes JR et al. Elemental sulfur use and associations with pediatric lung function and respiratory symptoms in an agricultural community (California, USA). Environ Health Perspect. 2017;125.

92. Savitz DA, Wellenius GA. Invited Commentary: Exposure Biomarkers Indicate More Than Just Exposure. Am J Epidemiol. 2018;187:803-5.

93. Manzano-Salgado CB, Casas M, Lopez-Espinosa MJ et al. Prenatal exposure to perfluoroalkyl substances and cardiometabolic risk in children from the spanish INMA birth cohort study. Environ Health Perspect. 2017;125.

94. Gauderat G, Picard-Hagen N, Toutain PL et al. Prediction of human prenatal exposure to bisphenol $\mathrm{A}$ and bisphenol A glucuronide from an ovine semi-physiological toxicokinetic model. Sci Rep. 2017;7.

95. Perrier F, Giorgis-Allemand L, Slama R, Philippat C. Within-subject pooling of biological samples to reduce exposure misclassification in biomarker-based studies. Epidemiology. 2016;27:378-88.

96. Wild CP. The exposome: From concept to utility. Int J Epidemiol. 2012;41: 24-32.

97. Canfield RL, Henderson CR, Cory-Slechta DA, Cox C, Jusko TA, Lanphear BP. Intellectual impairment in children with blood lead concentrations below $10 \mu \mathrm{g}$ per deciliter. N Engl J Med. 2003;348:1517-26.

98. Lanphear BP, Hornung R, Khoury J et al. Low-level environmental lead exposure and children's intellectual function: An international pooled analysis. Environ Health Perspect. 2005;113:894-9.

99. Grandjean P. Only One Chance: How Environmental Pollution Impairs Brain Development. New York: Oxford University Press; 2013.

100. Health and Environment Alliance | FIGO, UCSF and HEAL share 10 tips to avoid toxic chemicals during and after pregnancy. Available at: https:/ / www.env-health.org/figo-ucsf-and-heal-share-10-tips-to-avoid-toxicchemicals-during-and-after-pregnancy/. Accessed August 28, 2020.

101. Safer Chemicals, Healthy Families. Get the facts. Available at: https:// saferchemicals.org/get-the-facts. Accessed 29, August 2020.

102. Vrijheid M, Casas M, Gascon M, Valvi D, Nieuwenhuijsen M. Environmental pollutants and child health-A review of recent concerns. Int J Hyg Environ Health. 2016;219:331-42. 